\title{
U economics

Emergence and development of a financial cluster: the evolution of Andorra's banking deposits in the long-term, 1931-2007

Marc Galabert Macià 


\title{
Emergence and development of a financial cluster: the evolution of Andorra's banking deposits in the long-term, 1931-2007
}

\begin{abstract}
This paper explores the origins of Andorra's financial cluster. It shows that the free movement of currency, the protection of infant industry, and geographical concentration lie at the foundation of the cluster's competitive advantage. Drawing on a new set of data, the paper also provides for the first time an estimate of the total deposits held by Andorra's banks between 1931 and 2007. Based on this new information, the paper reaches the conclusion that the development of the cluster went through four distinct phases in which large companies, acting as leaders, played an important role in enhancing the cluster's business capabilities.
\end{abstract}

JEL Codes: E42, G21, L16, N84.

Keywords: Competitive advantage, Cluster lifecycle, Financial system, Leading firms, Infant industry protection.

Marc Galabert Macià

Universitat de Barcelona

Acknowledgements: This study has benefited from feedback received in the doctoral seminar of the Department of History and Economic Institutions of the University of Barcelona and particularly from the valuable input and reading of Dr. Jordi Catalan Vidal. I would also like to thank Dr. Carles Sudrià Triay and Dr. Yolanda Blasco Martel for their helpful comments. Any errors remain the sole responsibility of the author. 


\section{Introduction}

This paper presents an estimation of the total deposits held by Andorra's banking system between 1931 and 2007. Throughout the twentieth century, Andorra rose to become one of the leading offshore banking clusters in southern Europe. Today, banking is one of the most dynamic activities in Andorra's economy. Its relative share of GDP is in the region of 20 per cent. Historically, the country has been characterized by the absence of a central bank, the free movement of currency, banking secrecy and no taxes on savings income prior to 2005. In that year, the ratio of deposits to GDP was 285 per cent. In Spain, one of the countries with the highest banking coverage in Europe, this ratio did not exceed 91 per cent (Ruiz 2007, p. 126). In 2007 the total wealth under management in Andorra was 10 times greater than GDP.

Nonetheless, literature on the evolution of Andorra's banks remains scarce due to the sector's poor regulation and its secrecy. Previous studies have stressed the centrality of banking to the Andorra economy and its role in channelling savings into the international market (Sogues 1975; Arasanz 1986; Lluelles 1991; Garcia 2001; Gurdó 2006; Sáez 2004; Cabana 2005). However, research has not provided a comprehensive long-term view of the sector and in some cases offers no quantitative measures of its evolution.

The aim of this study is to analyse the lifecycle of Andorra's banking industry. The paper also shows the contribution made by specific firms to the creation of the sector's competitive advantage. The major new source of information offered here is Crèdit Andorrà's annual reports from 1957 to 1983, which stand as a significant addition to the available data. Use is also made of documents from the National Archive 
of Andorra (hereafter NAA) and the Archives of the General Council of Andorra (hereafter AGCA) to analyse legislative developments in the sector (Annex 1). ${ }^{1}$

\section{Evolution of Bank Deposits as a Lifecycle Measure}

Andorra's Department of Statistics started publishing banking data in 1989. For previous periods, the available references are scattered and piecemeal. Examples in print include published interviews with banking professionals and texts collected within commemorative books. Sogues (1975) presents client liabilities for Andorra's banking sector for the period 1970-1973 based on sector information. Gurdó (2002) gathers data on the Mora Bank Group (Banc Internacional d'Andorra and Banca Mora, or BIBM) from a book celebrating the firm's fiftieth anniversary. Cabana (2005) contributes data on Banc Agrícol i Comercial d'Andorra and Banca Reig for the period 1931-2001 drawn from the commemorative book published on the occasion of the two firms' merger.

This paper provides for the first time an aggregate estimate of total deposits held by Andorra's banks in the period 1931-2007. In addition to bringing together this scattered data, the paper also includes information from Crèdit Andorrà's annual reports for the period 1957-1983. Bearing in mind that between 1989 and 2007, a period for which we have complete information, Crèdit Andorrà's market share hovered in the region of 35 per cent, the inclusion of this earlier data is crucial for understanding the evolution of Andorra's banking sector. The estimate draws on the data of a total of six firms. Because it has not been possible to obtain data for the Andorran subsidiary of Caixa d'Estalvis i Pensions de Barcelona, active in the country between 1934 and 2007, 
its volume of deposits is not included. Even so, it is known that its funds had risen to 39.68 million pesetas by the end of 1959 (Nadal and Sudrià 1981, p.380).

To calculate the estimate, it is assumed that banks, in any years without available data, achieved a growth in deposits equivalent to the average growth of all firms included in the calculation of the aggregate. This may not be the most reasonable criterion at an individual level, but it does provide valuable information on the general trend in the sector. In addition, most banks were set up as foreign exchange businesses. As no assurances can be given that they accepted deposits, the assumption is made that banks began to receive deposits in the year that they obtained their license. To adjust the data set for inflation, the estimation uses the Spanish consumer price index put forward by Carreras and Tafunell (2004).

Figure 1

Estimation of Andorra's bank deposits 1931-2007 (in 1950 pesetas)

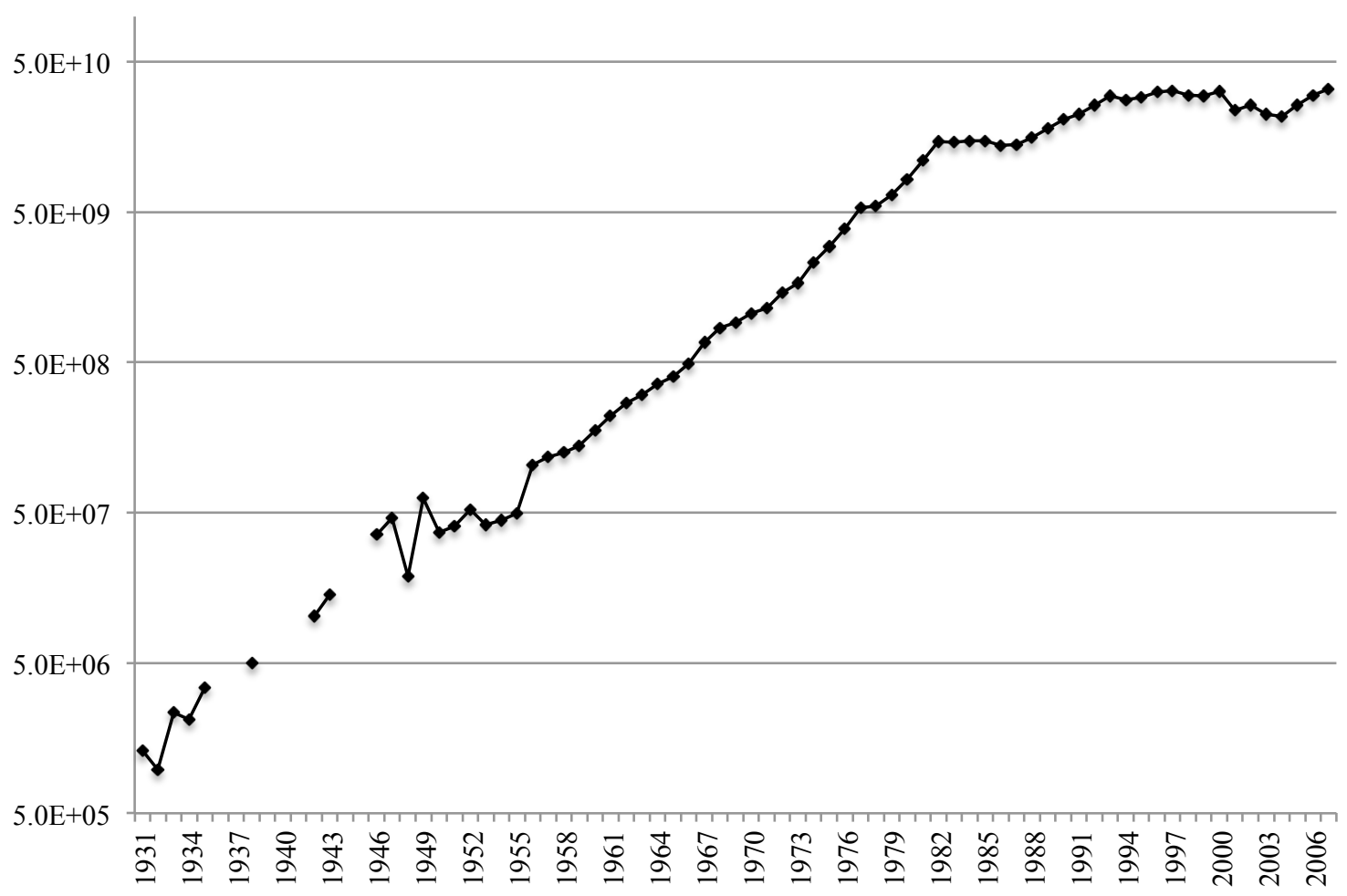


Historically, Andorra has not had its own currency. ${ }^{2}$ Throughout the twentieth century, the French franc and the Spanish peseta were both used in the country, although the peseta was more widespread. The budgets of the General Council were prepared in pesetas, most salaries were paid in pesetas and bank deposit data were reported in pesetas.

\section{Table 1}

Real cumulative annual growth of bank deposits in Andorra for 1931-2007 (in percentages)

\begin{tabular}{ccc}
\hline Period & PTA 1950 & FF 1950* \\
\hline $1931-1947$ & 24.9 & 25.6 \\
\hline $1947-1957$ & 9.8 & -2.6 \\
\hline $1957-1982$ & 21.4 & 29.5 \\
\hline $1982-2007$ & 3.3 & 7.6 \\
\hline
\end{tabular}

Source: Own preparation.

* Adjusted for inflation using Sédillot's French consumer price index (1979) and data from the World Bank.

Adjusting the data in the two currencies for inflation provides evidence of similar trends in the evolution of deposits. In figure 1, four stages can be identified in the lifecycle of the cluster. ${ }^{3}$ Between 1931 and 1947 deposits grew at a rapid, but erratic pace. Between 1947 and 1957, the pace of new deposits slackened significantly compared to the previous period. From 1957 until 1982, the sector saw a sustained period of hypergrowth. Lastly, from 1982 to the end of the data set, the growth in deposits lost steam and became more modest, experiencing alternating positive and negative growth rates. 
Table 2

Percentage of deposits in Andorra by bank, 1957-2007

\begin{tabular}{|c|c|c|c|c|c|c|c|c|}
\hline Year & $\begin{array}{c}\text { Banc } \\
\text { Agrícol } \\
\end{array}$ & $\begin{array}{c}\text { Banca } \\
\text { Reig }\end{array}$ & BIBM & $\begin{array}{c}\text { Crèdit } \\
\text { Andorrà }\end{array}$ & Andbank & $\begin{array}{c}\text { Banc } \\
\text { Sabadell } \\
\end{array}$ & $\begin{array}{c}\text { Cassany - } \\
\text { BPA }\end{array}$ & $\begin{array}{c}\text { Mercantil- } \\
\text { Sobanca }\end{array}$ \\
\hline 1957 & 28.4 & 7.1 & 21.7 & 33.6 & - & - & 6.5 & 2.8 \\
\hline 1970 & 21.1 & 3.8 & 23.4 & 44.8 & - & - & 6.9 & - \\
\hline 1980 & 26.3 & 2.5 & 37.9 & 26.5 & - & - & 6.9 & - \\
\hline 2007 & - & - & 26.2 & 36.1 & 20.0 & 5.4 & 12.4 & - \\
\hline
\end{tabular}

Source: Own preparation.

By estimating deposits, it is possible to analyse the role played by the various banks in the configuration of the cluster. On the whole, scholars of industrial organization draw the conclusion that the geographical concentration of companies in districts or clusters fosters the appearance of competitive advantages. However, they hold opposing views regarding company size in the creation of competitive advantage. Proponents of small-scale business take inspiration from the development of neoMarshallian districts in the so-called Terza Italia, or Third Italy. They stress that a large number of small firms makes the Marshallian district highly dynamic and flexible, better able to adapt to demand and to manage the use of the workforce. They argue that the drawbacks of a small scale are outweighed by the value of cooperation when creating business networks and purchasing inputs jointly (Becattini 1979, Brusco 1982, Sforzi 2009). On the other side, some authors see a source of competitive advantage in the capabilities of large companies (Chandler 1987, Landes 1988, Markusen 1996). They underscore that the successes of the US and Germany during the Second Industrial Revolution exploited economies of scale generated by clusters in which large businesses were predominant. Along the same lines, tertiary clusters such as the high-tech industry 
in Silicon Valley or the film industry in Hollywood are led by large businesses. Together with economies of scale, it seems clear that strategy, organizational learning, management capability and process improvement make the large company a major source of internal economies.

In the case of Andorran banking, the estimation of deposits points to a clear hierarchy among the firms in the cluster (Table 2). Between 1957, the year in which the opening of new firms was prohibited, and 2007, the two banks with the greatest market share accounted for over 60 per cent of deposits. The advantages stemming from banking concentration in Andorra were reinforced by the existence of large firms that acted as leaders in contributing to the improved business capabilities of the cluster.

\section{Origins of the Cluster, 1930-47}

In 1930, Andorra ended the licensing policy that had been in force since the midnineteenth century. ${ }^{4}$ During this period, the country had sought to modernize a predominantly rural economic structure by granting licenses for gaming, thermal springs and postal services. With the advent of the twentieth century, concessions for the exploitation of natural resources were proposed. After a score of failed projects, the co-princes pushed forward a hydroelectric power station (Lluelles 2004, p. 35). The concession, which was granted to a Spanish-French investment group instigated by the Catalan industrialists Damià Mateu Bisa and Miquel Mateu Pla, also brought with it exclusive banking rights and, in return, stipulated the construction of the country's road network. ${ }^{5}$ On 5 March 1930, the group set up Forces Hidroelèctriques d'Andorra S.A (hereafter FHASA). The electricity generated by the plant went to the industrial area of Barcelona and permitted the electrification of Andorra. 
On 30 December, nine months after the creation of FHASA, the first bank in Andorra was founded: the Banc Agrícol i Comercial d'Andorra. The bank's charter stipulated that the firm would remain exempt from any tax burden and that any other banks set up in the country would attract a 5 per cent tax rate on their operations to be divided in half between the General Council and the concessionary bank. ${ }^{6}$ Not possessing its own currency, Andorra could not control or limit currency circulation. The lack of institutional regulation led de facto to the establishment of banking secrecy.

Banc Agrícol launched operations in July 1931. The entirety of its start-up capital was Catalan in origin. Investors included the Mateus, who held a majority stake; Joan Fornesa and Bonaventura Rebés, who were the owners, respectively, of Banca Fornesa and the branch of Banca Arnús in La Seu d'Urgell; and Lluís Desvalls Trias, the Marquis d'Alfarràs, who was associated with La Caixa d'Estalvis i Mont de la Pietat de Barcelona (Cabana 2005, p. 37). In 1934, the strong relationship between the Mateus and Francesc Moragas, chairman of La Caixa de Pensions de Barcelona, led Banc Agrícol to authorize the opening of one branch of the La Caixa de Pensions de Barcelona, limited to savings accounts. ${ }^{7}$

The outbreak of the Spanish civil war in 1936 initiated a critical period for the Andorran economy that lasted until the end of World War II. The conflicts hindered the country's supplies. Shortages and rising inflation led to price controls and the regulation of foreign trade. In 1936 and 1937, the scarcity of coinage led the General Council to issue pesetas backed by the Spanish central bank (Turró 2007, p. 53). Smuggling rose sharply. Andorra, as a country bordering both France and Spain, benefited economically from its geographical location, introducing all kinds of products to its two neighbours, particularly tobacco, hides, wool and automotive parts (Lluelles 1991, p. 253). Andorra's neutrality also made it a safe haven for currencies. The demand of refugees 
from the Spanish civil war for French francs fuelled currency exchange in the country. World War II, the high post-war inflation of the franc and the appearance of parallel market rates for the peseta and the franc also appear to have played a role in the influx of capital into Andorra. ${ }^{8}$ The evolution of deposits makes it possible to approximate the monetary impact of the Spanish and global conflicts. Although the data are not continuous in these early years, deposits grew between 1931 and 1947 at a real cumulative annual rate of 24.9 per cent. To that end, the General Council passed laws against speculation so as to prevent harm to the domestic economy. Foreigners were prohibited from any unauthorized purchase or sale of currency and all payments were required to be made in pesetas. ${ }^{9}$ Despite the constraints, however, the prospects offered by foreign exchange encouraged some Andorrans to take up the currency business. In the nineteen-thirties and forties, at least six cases can be identified.

Table 3

Origins of Andorra's Banking Cluster

\begin{tabular}{|c|c|}
\hline Foreign exchange firms & Year set up \\
\hline Banc Agrícol i Comercial d'Andorra & 1930 \\
\hline Caixa d'Estalvis i Pensions de Barcelona & 1934 \\
\hline Josep Cassany & $1937 \mathrm{c}$ \\
\hline Lluís Aymat & $1937 \mathrm{c}$ \\
\hline Jane Huillier & $1937 \mathrm{c}$ \\
\hline Josep Josa & $1937 \mathrm{c}$ \\
\hline Bonaventura Riberaygua Argelich & $1937 \mathrm{c}$ \\
\hline Le Comptoir Andorran de Change & 1938 \\
\hline
\end{tabular}

Source: Own preparation. 
In 1937 Lluís Aymat d'Encamp, Jane Huillier and Josep Josa d'Escaldes were running a currency exchange firm. ${ }^{10}$ Josep Cassany, founder of Banca Cassany, remarked in his memoirs that he, too, was engaged in currency exchange during the Spanish civil war (Cassany 1999, p. 10). Bonaventura Riberaygua Argelich, secretary of the General Council between 1935 and 1950, drew on his experience in foreign exchange during the war as support in his application to set up Crèdit Andorrà. ${ }^{11}$ In 1938 Bonaventura Mora Munt established Le Comptoir Andorran de Change, a foreign exchange office that maintained banking correspondence with Tangier through the Societé de Banque Suisse (Gurdó 2002, p. 15).

The Spanish civil war and World War II were a historic shock for Andorra's economy. The country acted as a safe haven for currencies amid surrounding monetary instability. With the end of the conflicts, the country's introduction into global trade and the regulation of goods moving through France and Spain enabled the country to benefit from international imports arriving from two directions. This reflected the post-war complementarity of needs in Andorra's two neighbouring markets which, together with the absence of excise taxes, helped to give rise to a powerful trade and tourism sector aimed at French and Spanish consumers (Bricall et al. 1975, Lluelles 1991, 2004, Comàs d'Argemir 2002, Galabert 2012). The growth in funds deposited in Andorra's banks and the existence of moneychangers shows how the country's neutrality acted as an initial perturbation for the emergence of a cluster based on the competitive advantage arising from the free movement of currencies. 


\section{Growth in Critical Mass, 1947-57}

The end of the Spanish civil war and World War II halted the influx of refugee capital into Andorra. European currency restrictions forced the country's banking sector to operate primarily with Swiss banks. The general shareholders' meeting of Banc Agrícol on 18 June 1949 expressed the difficulty of conducting operations with France and Spain due to foreign exchange controls. In order to maintain a 'good neighbour' policy, large amounts of currency were not accepted even though currency exchange operations were the bank's most profitable business. In 1948, the cancellation of a French correspondent's current account, which represented half of the bank's deposits, shows how difficult it was to operate with Andorra's neighbours (Cabana 2005, p. 58-59).

In the previous year, Miquel Mateu had put half of his shares up for sale. He had become the principal shareholder in the bank after inheriting his father's shares upon the elder Mateu's death in 1935. Trias Desvalls followed suit, selling all of his shares. Mateu left Banc Agrícol in 1948, although he continued to serve as honorary chairman until 1973. His shares were purchased by Manuel Cerqueda Escalé, director of the bank since 1931, making Cerqueda the principal shareholder, and by Bonaventura Riberaygua Argelich, whose stake rose to 12 per cent. For their part Fornesa and Arnús, who had sold their respective stakes to Banco Español de Crédito between 1943 and 1946, made way for Josep Coma Maestre and Xavier Sansa Nequi, who were a merchant and a lawyer, respectively, and who then took seats on the bank's board of directors (Cabana 2005, p. 51).

Andorra's economic conditions during the Spanish civil war and World War II resulted in the emergence of new fortunes. Monetary expectations provided incentives to expand businesses in the country's banking sector. 
At the end of 1949, Bonaventura Riberaygua Argelich, a shareholder in Banc Agrícol and secretary of the General Council since 1935, requested authorization to found a credit institution with the name Crèdit Andorrà, of which he would be the sole owner and his son Ramon Riberaygua Esteve would serve as managing director. The General Council approved his request. ${ }^{12}$ In early 1950 Bonaventura Riberaygua Argelich died and his shares in Crèdit Andorrà and in Banc Agrícol, together with his post as secretary of the General Council, passed down to his son. ${ }^{13}$

Pursuant to the concessionary contract of 18 April 1929 which stipulated that Banc Agrícol was entitled to manage the collection of a 5 per cent tax on the operations of any other banks that happened to set up offices in the country, the firm lodged a complaint with the veguers (Andorra's chief magistrates) that led to the suspension of the authorization given by the General Council to Crèdit Andorrà. ${ }^{14}$ Faced with this situation, the General Council then took further action in late 1950, opening an investigation to determine the legality of the original concession of exclusive banking rights made by the General Council back in 1929. In April 1951, the investigation concluded that the Council could not view the tax of 5 per cent on banking operations as irrevocable, given that 'the powers inherent to the General Council are only those related to administration, never to the absolute disposition of the country's patrimony, the citizens' absolute and inalienable property'. Now it was established that the 'administration could rescind any agreements that were harmful to the interests over which it governs ${ }^{, 15}$.

In light of these considerations, the General Council acted on 20 July 1951 to repeal any earlier provision on the subject of banking and went on to establish the requirements that had to be met by any firms wishing to enter banking or foreign exchange. Among the key points to underscore were the disbursement of a million 
pesetas or the sum's equivalent in French francs at the time of founding, and the requirement that all capital must belong to Andorran citizens. ${ }^{16}$ Later foreign stakes were restricted to a third of any company or bank's share capital. ${ }^{17}$ This policy, which was strongly protectionist in nature and analogous to the regulation of limited companies in 1940, was motivated by a strategy aimed at infant industry protection in the face of international competition (Chang 2004, p. 49-133.; 2012, p. 87-98). Syndic Francesc Cairat and secretary Ramon Riberaygua, owner of Crèdit Andorrà, who thereby saw the temporary suspension of his firm's activities lifted, signed the legislation. The new regulation promoted the creation of new banks, setting in motion a national trend in entrepreneurship that introduced competition and gave the sector its critical mass.

On 6 June 1952 Le Comptoir Andorran de Change, founded as a foreign exchange office by Bonaventura Mora Munt in 1938, obtained authorization from the General Council to become Crèdit Comercial d'Escaldes. This increased the relations instigated by Le Comptoir with La Societé de Banque Suisse and Le Crédit Mobilier de Tanger. On 12 September 1956, Crèdit Comercial d'Escaldes became Banca Mora under the decree of $1951 .{ }^{18}$ On 18 April 1956, Julià Reig Ribó, a tobacco manufacturer and owner of Tabacs Reig, received authorization from the General Council to enter banking $^{19}$. On 21 April 1956 Banca Reig was created. ${ }^{20}$ On 13 July 1956 Josep Coma Maestre, a merchant mainly dedicated to the import-export business and a former board member of Banc Agrícol, was authorized to found Banca Coma. ${ }^{21}$ On 17 April 1957 Josep Cassany Grau obtained permission to set up Banca Cassany ${ }^{22}$, in which Banque Nationale de Paris took an early stake. On 15 June 1957 the General Council authorized Josep Cuberes Dolsa, an industrialist, to create the Banc Immobiliari i Mercantil d'Andorra. ${ }^{23}$ The opening ceremony, which had a significant impact in the press, was 
attended by leading figures in the country as well as by representatives of the Moroccan Real State and Commercial Bank, which gave technical support to the new firm. ${ }^{24}$ In September 1957 the co-princes expressly prohibited any new authorization for the foundation of additional banks until the profession of banker was regulated, due to the rise of the figure of the nominee in the country. ${ }^{25}$

\section{Table 4}

\section{Andorra's Banking Cluster in 1957}

\begin{tabular}{cc}
\hline Banks & Year of establishment \\
\hline Banc Agrícol i Comercial d'Andorra & 1930 \\
\hline Caixa d'Estalvis i Pensions de Barcelona & 1934 \\
\hline Crèdit Andorrà & 1949 \\
\hline Banca Mora & 1956 \\
\hline Banca Reig & 1956 \\
\hline Banca Coma & 1956 \\
\hline Banca Cassany & 1957 \\
\hline Banc Immobiliari i Mercantil & 1957 \\
\hline
\end{tabular}

Source: Own preparation

Between 1947 and 1957 the resources of third parties in Andorra's banks grew, on average, by 9.8 per cent annually in real terms. Despite the fact that the benefits from neutrality had evaporated, the banking sector expanded its critical mass throughout the period. The creation of new banks was sparked by opportunities to exploit the revealed competitive advantage arising out of the non-convertibility of European currencies. In particular, one of the chief factors behind the emergence of banking in Andorra was the distorted monetary policy of the early Franco regime (Viñas 1979, p. 268-81; Catalan 1993, p. 121; 1995, p.117; 2003, p. 139; Serrano and Asensio 1997, p.549). One 
downside of the Franco regime's policy was that it encouraged capital flight amid the high inflation assailing Spain. It also entailed the financing of imports from abroad thanks to the availability of foreign currency (Cabana 2005, p. 67; Viñas 1979, p. 802). The destabilization of the Spanish balance of payments and the collapse of the peseta's rate of exchange in the free market of Tangier from 1956 onwards produced an immediate effect: pesetas were transferred to Andorra to be exchanged for other currencies (Viñas 1979, p. 825). ${ }^{26}$ The concentration of new banks created that year, their ties to Tangier, and the takeoff in deposits from that date onwards support this view (IMF Country Report 2007, p. 9).

The entrepreneurial bent that characterizes this period is a result of economic activities fostered during the critical period of the Spanish civil war and World War II. Wartime currency exchange, tobacco and livestock exports, and post-war trade generated the original accumulation that permitted the creation of Andorra's banks. In order to exploit the opportunities in the environment, the new fortunes in the country forced competition into the sector. The profits gained from neutrality were sunk into the creation of a financial cluster that drew on competitive advantage from currency exchange. The strategy in favour of infant industry protection and the prohibition against granting authorization to new banks were crucial policies for the formation of a sector protected from foreign competition and dominated by local firms.

\section{The Boom, 1957-82}

The creation of the cluster shook up the sector and attracted foreign banks. In 1960 the cluster's main institution was set up: the Association of Andorran Banks. The association brought all local banks together in order to institute self-regulation, defend 
the interests of members and boost the corporate image of Andorra's financial centre. In the same year, Banca Mora acquired Banca Coma. Ten years later, Banco de Bilbao took a stake in Banca Coma, purchasing 33.3 per cent of its shares, and the firm was renamed Banc Internacional. In 1973, Banc Internacional purchased Banca Mora, creating the Banc Internacional-Banca Mora Group. In 1967 Banco Popular Español acquired a stake in Crèdit Andorrà. Rafael Termes, whose ties to Crèdit Andorrà dated from the institution's beginnings and who had been CEO of Banco Popular Español since 1966, sold his 15 per cent stake in Crèdit Andorrà to Banco Popular Español (Serrano 1998, p. 124). In the early nineteen-seventies, La Banque d'Indosuez bought another 15 per cent in the bank. The experience that foreign firms brought to these banks played an important part in enhancing their business capabilities and promoting the creation of sector leaders.

In this period, the cumulative annual growth rate of Andorra's banking sector was, on average, 21.4 per cent in real terms. The convertibility of European's main currencies in late 1958 did not erode the sector's competitive advantage. As had occurred with the US dollar since 1945, convertibility was only applied to currentaccount movements. Private capital transactions outside the balance of trade were restricted in order to avoid speculative movements that could damage the stability of fixed exchange rates (Eichengreen 1996, p. 163; 2007, p. 84). Because Andorra did not have its own currency, it remained on the regulatory fringes. The ability of Andorra's banks to hold accounts in foreign currencies acted as an incentive for inflows of speculative capital. ${ }^{27}$ Banking secrecy and the absence of taxes meant a lack of cooperation with neighbouring countries. This state of affairs essentially made Andorra an offshore haven for foreign capital. This is the context in which devaluation of the peseta undertaken as part of Spain's Stabilization Plan of 1959 precipitated Spain's 
nine-month closure of the border with Andorra. The argument was that Andorra possessed speculators who had previously been established in Tangier (Giral 1988, p. 33). Despite measures adopted by the General Council so as not to undermine the currencies of neighbouring countries, the wealth of third parties held in Andorra's banks that year rose by 11.5 per cent in real terms with respect to the previous year. ${ }^{28}$

Andorra's banking model, once the domestic demand for credit had been met, was based on attracting French francs and Spanish pesetas which were then converted into foreign currencies because of inflation or the risk of devaluation and put into fixedincome securities and deposits in correspondent banks abroad. Internally, they held short-term positions in pesetas and francs to finance the country's trade flows. This enabled them to avoid working with the Spanish or French interbank. As a consequence, however, the scarcity of pesetas or francs sometimes gave rise to lending in foreign currencies (Arasanz 1986, p. 94-102; Lluelles 1991, p. 435-40; Cabana 2005, p. 108).

In 1968 La Societat de Banca Andorrana (hereafter Sobanca) collapsed. Sobanca had been created in late 1959 when the name and shareholders of Banc Immobiliari i Mercantil were changed. The new owners, mainly foreign corporations represented by Andorran trustees, embarked on a policy of risky investments in Andorra and abroad (Cabana 2005, p. 93). The new shareholders included Julio Muñoz Ramonet. ${ }^{29}$ In the late nineteen-fifties, Muñoz had held a majority stake in Banque Genevoise de Commerce et Crèdit and in Schweizerische Spar- und Kreditbank - St. Gallen. Between 1963 and 1965, after these two banks had given large loans to various companies owned by Muñoz, an investigation launched by the Union des Banques Régionales came to the conclusion that Banque Genevoise had lost half of its equity capital. In 1965 both banks were forced to shut their doors. To straighten out what became known as "the first major Swiss banking scandal", the Union des Banques Suisses reached an agreement 
with Muñoz to assume the assets and liabilities of the two banks in exchange for 16 million Swiss francs and various additional safeguards. One of the safeguards involved Sobanca, which was being overwhelmed by events. Accordingly, Sobanca passed a resolution to dissolve on 15 June 1968. The collapse of the firm pushed Andorra's banking sector into a tight corner, because there was no legislation governing the bankruptcy of a firm or its suspension of payments. In response, the Association of Andorran Banks, acting in conjunction with the General Council and the representatives of the co-princes, reached an agreement that the remaining banks would take over Sobanca's obligations in order to present a sound and reassuring image of the sector. In return, the co-princes reiterated to the General Council their rejection of the granting of authorization to new banks. ${ }^{30}$

Figure 2

Spanish and French tourists visiting Andorra, 1961-89

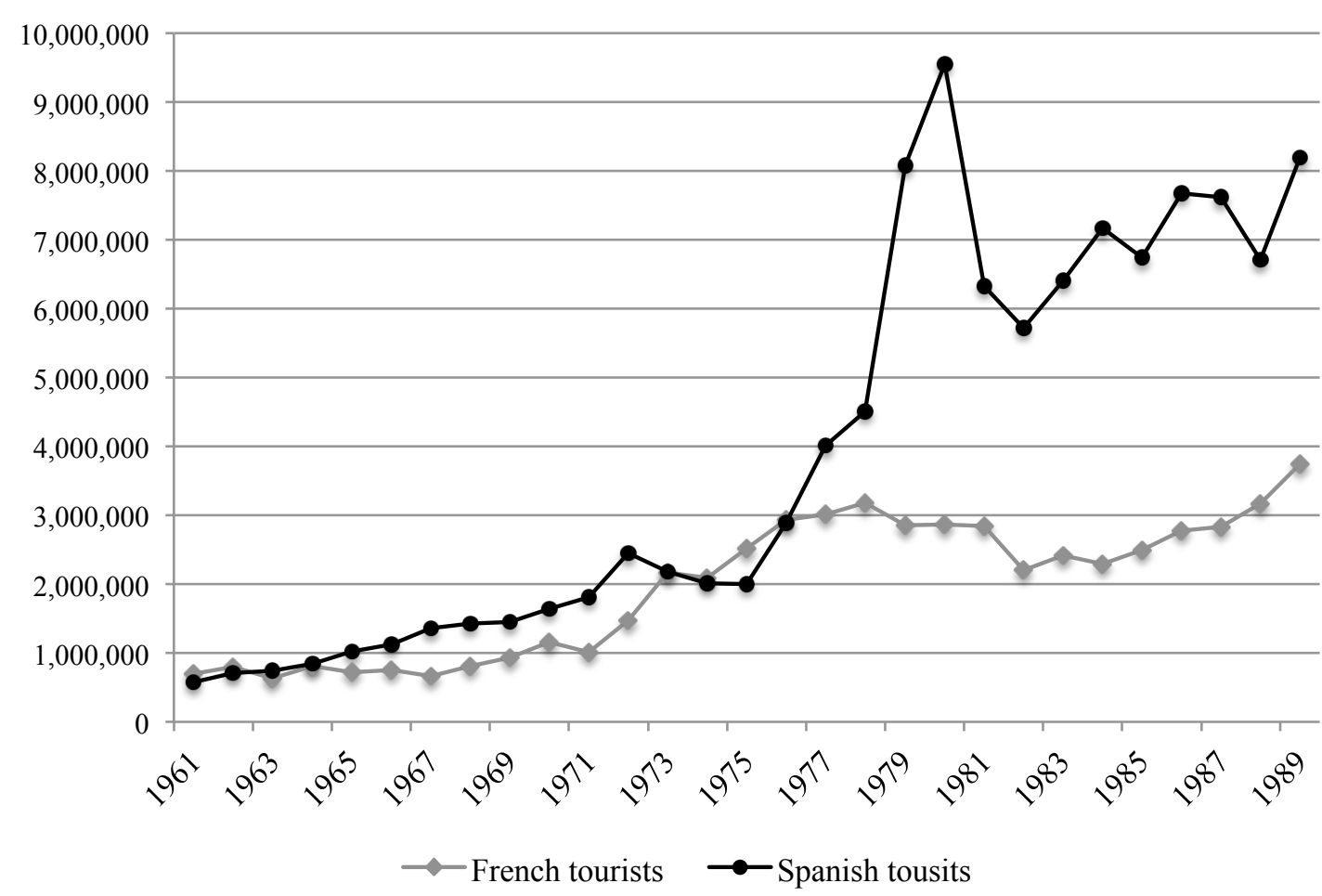

Source: (Bricall et al. 1975 and Lluelles 1991) 
In the nineteen-seventies, Andorra's banking sector consolidated its growth. Instability stirred up by the collapse of the Bretton Woods international monetary system in 1971, the oil price shocks of 1973 and 1979 and Spain's transition to democracy in the wake of Franco's death in 1975 strengthened the country's status as a safe haven. The use of the peseta as an accommodative policy tool in the Spanish recession served as a major incentive to move Spanish capital to Andorra.

Between 1975 and 1980, Spanish tourism in the principality grew by a factor of 4.78 (figure 2). Over the same period, the deposits kept by third parties in Andorra's banks grew by 178.2 per cent in real terms. The importance of Spanish tourism and capital in Andorra turned the country into the top offeror of europesetas in the world (Lluelles 1991, p. 439). These would have been purchased by Siaguins, a subsidiary of the Spanish central bank whose mission was to support the parity of the peseta abroad. ${ }^{31}$ In 1979 the second oil price shock aggravated the European situation and sent inflation soaring. In the Spanish case, the excessive gradualism adopted with respect to the process of substitution and energy savings prolonged the effects of the oil price shock into the mid-eighties (Rojo 1994, p.196). High rates of inflation and the devaluation of the peseta in 1982 and of the franc in the early eighties once again spurred the movement of capital to Andorra.

\section{Maturity, 1982-2007}

In the nineteen-eighties, the growth of deposits in Andorra's banks eased back significantly with respect to previous periods. The chief causes of this trend can be found in the gradual liberalization of capital controls after the collapse of Bretton Woods, the gradual process of European integration and the growing monetary stability 
of Spain and France. Even so, between 1984 and 1987, 32 cases of illicit tax evasion flows were uncovered at the Spanish-Andorran border. ${ }^{32}$

In 1989 the growing need for public-sector finance led the General Council to lay groundwork for the regulation of the financial system, setting up the Andorran National Institute of Finance (whose Andorran acronym is INAF). The mission of the new body, the country's leading public institution in the financial sector, was to act as a central bank to manage public funds and the public debt. Following the path initiated by the public sector, the Association of Andorran Banks signed an agreement in 1990 relating to due diligence on the part of Andorra's banks and savings institutions. In the document, the maintenance of banking secrecy was self-regulated according to the Basel criteria on external oversight practices. The aim was to prevent the introduction of capital into Andorra that was of dubious origin or for the purpose of money laundering.

In 1990 the entry into force of the EU directive on the free movement of capital posed a major challenge to the cluster's competitive advantage. ${ }^{33}$ The directive did not take effect in Spain until 1993. Amid the crisis of the European Monetary System and speculative attacks on European currencies, Andorra's bank deposits continued to grow between 1991 and 1993. From 1994, however, the totally free movement of capital in neighbouring countries and the falling profitability of the US dollar and the British pound raised doubts about the continuing viability of the model. In that year, bank deposits in Andorra fell by 5.15 percent in real terms with respect to 1993.

With the adoption of the Constitution of Andorra in 1993, the country gradually implemented financial regulation. Between 1993 and 2000, some fifteen laws came into force to define the legal personality of the Association of Andorran Banks. Legislation laid out the banking sector's obligatory investment coefficients in the public debt, solvency ratios, liquidity, the banks' share capital, and deposit guarantees. Regulations 
addressed banking secrecy, disciplinary regimes, an increase in the percentage of foreign stakes in banks up to 51 per cent, the creation of new institutions and a common chart of accounts. In addition, ratification was given to the Vienna and Strasbourg conventions against the illicit traffic in narcotic drugs and against money laundering, respectively (Sansa 2001, p.77-251).

The prospect of monetary union at the turn of the century and the maturity of the model used to attract deposits caused the sector to change its business strategy. Ongoing EU monetary harmonization and the consequent reduction in arbitrage opportunities, the liberalization of international capital controls, the emergence of investment funds and the general fall in interest rates eroded the sector's traditional competitive advantage and encouraged it to draw more on tax advantages and banking secrecy than on the free movement of currencies. Faced with this situation, Andorra's banks followed the trend in neighbouring countries and took a more active role in the management of their resources (Sáez 2004, p. 399; IMF Country Report 2007, p. 6). Between 1995 and 2007, deposits lost top position to operations involving clients' financial assets (figure 3). While asset management accounted for roughly 22 percent of total funds in 1995, it was practically equal to deposits by 1998 and by the early years of the new century, it stood solidly in the region of 60 per cent. 
Figure 3

Distribution of resources in Andorra's banks in the period 1995-2007, by percentage

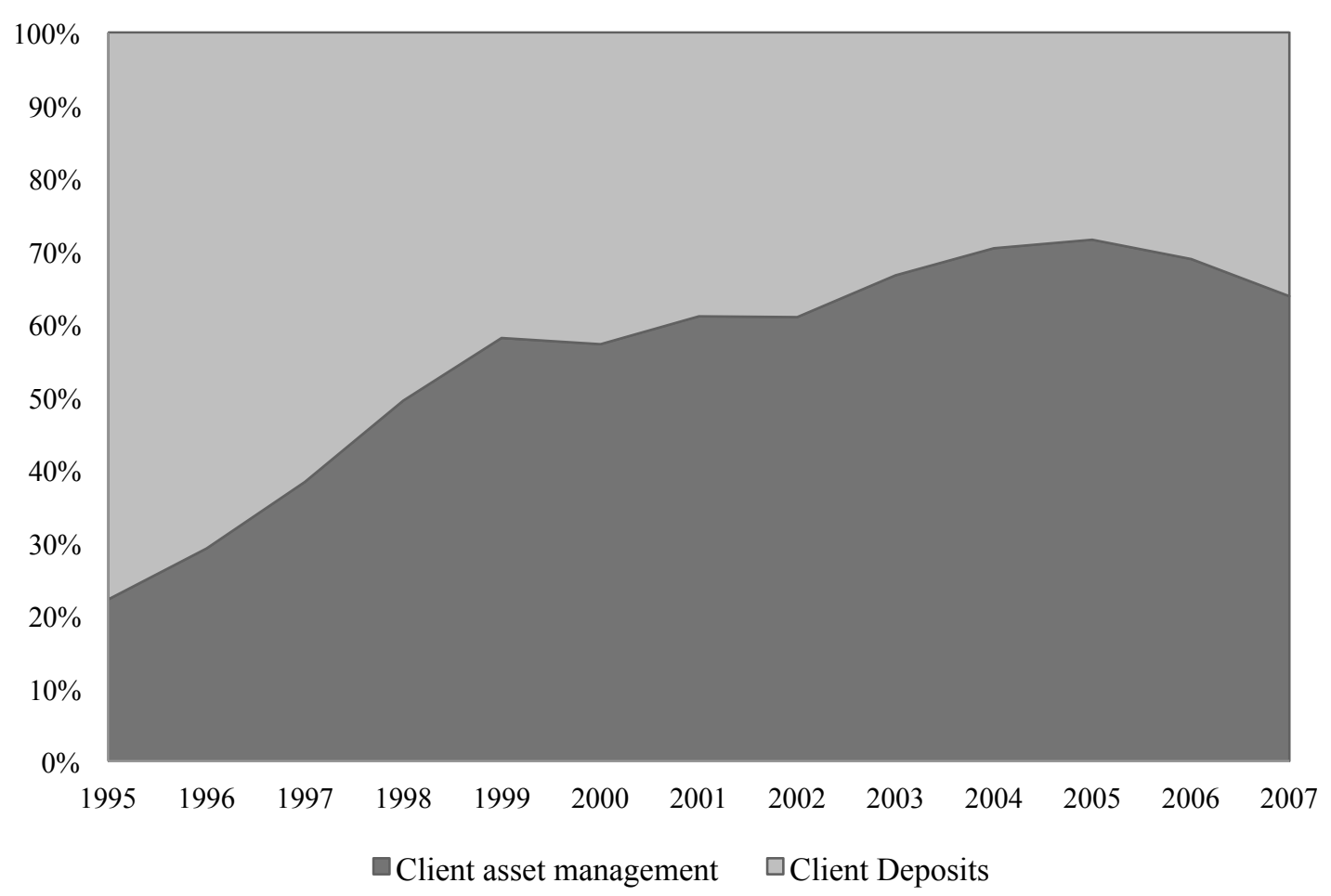

Source: Own preparation based on Sáez (2004) and Department of Statistics of Andorra

In the course of fifteen years, Andorra's banking model, which had emerged from the historic shock of the Spanish civil war and World War II, had lost its majority position and turned the focus of its specialization toward wealth management and offbalance-sheet operations. This shift also had an associated effect on the concentration of firms in the cluster.

In 1980 Banco Popular Español sold back its shareholding in Crèdit Andorrà. In 1986 Banque d'Indosuez sold its stake in Crèdit Andorrà to La Caixa de Pensions de Barcelona (Lluelles 1991, p. 434). Over 1993 and 1994 La Banque Nationale de Paris sold its shares in Banca Cassany to La Caixa de Catalunya. As a consequence of the operation, Banca Cassany was renamed Banca Privada d'Andorra (hereafter BPA). In 1997, as a result of financial regulation, La Caixa de Pensions de Barcelona, which had 
been present in Andorra since 1934, signed a special agreement with the Andorran government to found CaixaBank, which was to acquire all of the savings bank's assets in the country. In 2000 La Caixa de Catalunya sold its stake in BPA, which went on to have solely Andorran equity. The same year saw the foundation of Banc Sabadell d'Andorra, whose shares were 51 per cent owned by Banc Sabadell. Over 2000 and 2001, Banc Agrícol i Comercial d'Andorra and Banca Reig merged, creating Andbank. In 2005 CaixaBank withdrew from the Andorran banking market and its assets were acquired by Crèdit Andorrà. Also in 2005 a tax on savings income for EU nonresidents in the country came into force. ${ }^{34}$ Nevertheless, two years later, BBVA and La Caixa disposed of their stakes in Banc Internacional-Banca Mora and Crèdit Andorrà, respectively, on the advice of the Spanish central bank that Spanish institutions should not have shareholdings in banks in countries exempt from cooperative and fiscal legislation.

Change in the banking business, concentration, increasing specialization in private banking and the gradual international pressure to eliminate banking secrecy and tax advantages drove the banking cluster to take steps to manoeuvre and adapt. The protection of the sector against the onslaught of international competition gave Andorra's banks sufficient strength to begin a process of internationalization based on their know-how in wealth management. During the first decade of the twenty-first century, Andorra's banking cluster began to take positions in emerging markets such as Latin America and in recognized financial centres like Switzerland, Luxembourg, the Bahamas and Panama. 


\section{Conclusions}

The main contribution of this paper is the estimation of total deposits held by Andorra's banks in the period 1931-2007. Until now, this was a major gap in Andorra's economic literature. The estimate offers a complete picture of the development of Andorra's banks in the twentieth century. The data point to four distinct phases in the lifecycle of the country's financial cluster.

The main factor in the formation of the cluster was the free movement of foreign currencies in Andorra owing to the fact that the country did not have its own currency. During the Spanish civil war and World War II, this encouraged the creation of new currency exchange firms that handled capital seeking safe haven in the country. Conflict served to provide the initial perturbation that created the conditions for the appearance of a cluster specializing in currency exchange. At the close of World War II, growth opportunities in the environment spurred the emergence of a banking cluster through an entrepreneurial class who had amassed wealth in wartime and would force the sector open in 1951. The sector, however, was not thrown open completely. A strategy to defend infant industry included protection of the banking sector from international competition. The period from 1951 to 1957 saw the creation of most of the new firms, which gave critical mass to the cluster.

In 1957 Andorra's banking sector embarked on a period of growth. The free movement of currencies proved to be one of its main competitive advantages. In 1958 the convertibility of the leading currencies for business operations did not eliminate the possibility of transferring capital to Andorra and placing it on the international currency market. The country's lack of its own currency exempted it from the regulation of the International Monetary System, which made current-account convertibility widespread. The evolution of the volume of deposits held in Andorra's banks was strongly linked to 
the trajectory of the exchange rate of the French franc and, especially, of the Spanish peseta, reflecting the political and economic situations in those countries.

In the mid-eighties, the growth of third-party resources decelerated in light of the challenge posed by the gradual liberalization of international capital and Spain's entry into European Economic Community. The maturity of the business model pushed Andorra's financial cluster to take a more active part in the management of its clients' wealth. The early twenty-first century witnessed the consolidation of private banking as the sector's core business and its cumulative know-how gave rise to a new international growth strategy as an adaptive response of the cluster.

The political strategy of infant industry protection enabled the emergence of economies of scale. Between 1957 and 2007, the relative weight of each firm with respect to total deposits shows that the cluster, once formed, was dominated by two firms that held more than 60 per cent of all deposits. In the Andorran case, the advantages of geographical concentration were consolidated by the internal economies of leading firms that contributed to the creation of the cluster's competitive advantage. 


\section{Annex 1}

The Lifecycle of Andorra's Financial Cycle, 1930-2007
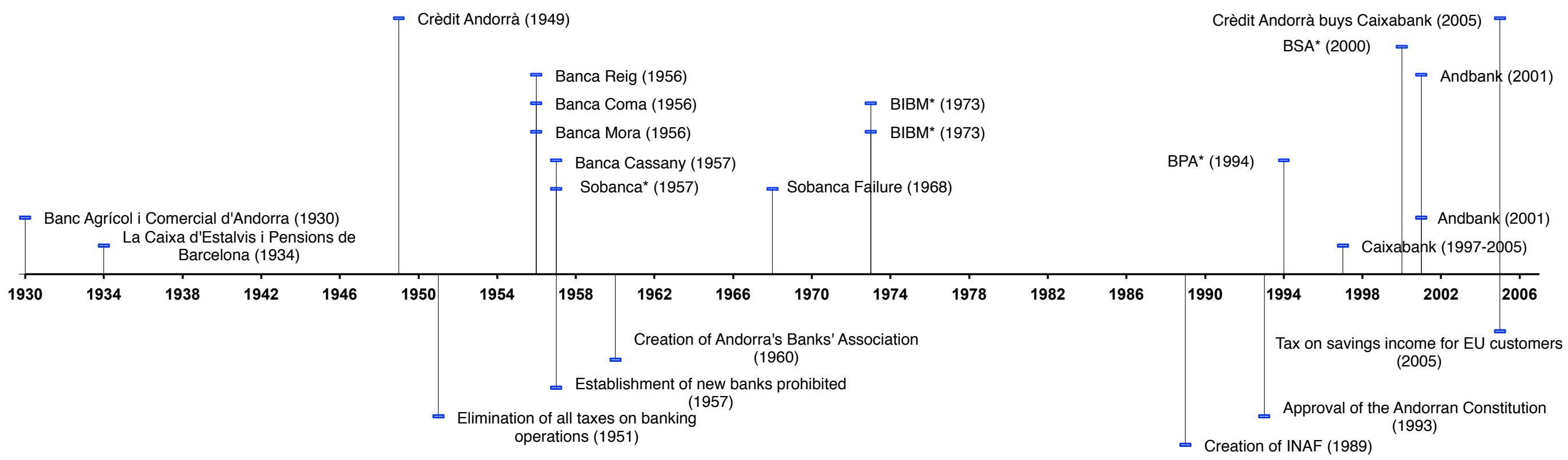

* BIBM: Banc Internacional - Banca Mora.

* BPA: Banca Privada d'Andorra.

* Sobanca: Societat de Banca Andorrana formerly Banc Immobiliari i Mercantil d'Andorra (1957-1959)

* BSA: Banc Sabadell d'Andorra. 


\section{Footnotes}

${ }^{1}$ Andorra is a small landlocked country in the Pyrenees that has been governed since 1288 by two co-
princes, the Bishop of Urgell and the Count of Foix (whose role was later transferred to the President of
France). Andorra's first parliament was created in 1419. Known as the Consell de la Terra, it was later
reformed and renamed the General Council. In 1993, the country approved a constitution that established
an effective separation of executive, legislative and judicial powers in the context of a sovereign state with the two co-princes serving as joint heads of state.

${ }^{2}$ Andorra does not have its own currency mainly because its domestic market is small. The country's limited size has fostered intense trade flows with neighbouring countries and encouraged the use of their currencies, which it has adopted as its own.

${ }^{3}$ While Klepper (1997), Maggioni (2005) and Maskell and Kebir (2005) identify three stages in the lifecycle of clusters, the evidence of this study points to four distinct stages, in line with Tichy (1998), Swann (2002), Bergman (2006) and Menzel and Fornahl (2007). For a thorough overview of the lifecycle of clusters, see Bergman (2008).

${ }^{4}$ Historically, Andorra's economy has been based on livestock, iron ore and tobacco as part of a web of trade relations that privileged France and Spain. During the second half of the nineteenth century, the spread of the Industrial Revolution in Europe undermined the competitiveness of Andorra's industrial activities. Faced with this state of affairs, the country undertook a policy of concessions involving its natural resources in order to modernize the structure of the economy.

${ }^{5}$ Born in Barcelona in 1898, Miquel Mateu Pla was the son of Damià Mateu Bisa and the grandson of Miquel Mateu Sans. Known as Mateu dels ferros for his ties to the iron and steel industry, he was a prominent Catalan industrialist and the co-owner of Hispano-Suiza, the carmaker and manufacturer of aircraft engines. He was also the principal shareholder in FHASA. Internationally, he had ties to highranking French and Spanish authorities and was a friend of Alfonso XIII of Spain, Franco and the French president. During the Spanish civil war, he aided the Fascist side. After the war, he held the office of mayor of Barcelona until 1945, was the head of the Catalan employers' association Foment del Treball and served as Spanish ambassador to France (Cabana 1996, p. 178-82).

${ }^{6}$ Decree of exclusive banking rights enacted on 18 April 1929 (AGCA).

${ }^{7}$ In 1927 La Caixa de Pensions de Barcelona asked the General Council for permission to open a branch 
office in the country. The request was denied because the General Council had not yet settled the granting of exclusive banking rights.

${ }^{8}$ For additional information on the post-war French economy, see Sédillot (1979), Asselain (1984, 2002), Saint Paul (1993) and Guyomarch (1999).

${ }^{9}$ Minutes of the General Council from the meeting of 22 March 1938 (NAA).

${ }^{10}$ Minutes of the General Council of Andorra from a meeting on 22 June 1937 (NAA).

${ }^{11}$ Decree $n^{\circ} 776$ of 21 December 1949 (AGCA).

${ }^{12}$ Decree $n^{0} 776$ of 21 December 1949 (AGCA).

${ }^{13}$ The beginnings of Crèdit Andorrà were marked by the close relationship of the petitioner with Ferran Valls i Taberner, appellate judge for the Principality of Andorra between 1916 and 1942. As a result, the main founders of the firm included the judge's sons Lluís and Xavier Valls-Taberner Arnó, together with Rafael Termes and the Andorran families the Fiters, the Casals, the Mases and the Pintats.

${ }^{14}$ Until 1993 the veguers, or chief magistrates, were the representatives of the co-princes in Andorra.

${ }^{15}$ Report on the legality of the Decree on exclusive banking rights issued on 18 April 1929 (AGCA).

${ }^{16}$ Banking Act of 20 July 1951 (AGCA).

${ }^{17}$ Regulation of Andorran limited companies enacted on 17 May 1940 (NAA).

${ }^{18}$ Decree n$^{\circ} 4209$ of 12 September 1956 (AGCA).

${ }^{19}$ Julià Reig Ribó (Sant Julià de Lòria, 5 Dec. 1911 - 2 Jan. 1996) is one of the leading figures in Andorra's political and economic life in the twentieth century. His career was focused on the management of the family tobacco factory, Tabacs Reig, and on the operations of Banca Reig. Politically, he was chosen in 1948 to sit on the General Council and served in that capacity until 1960, when he became general Syndic.

${ }^{20}$ Decree $n^{\circ} 4073$ of 18 April 1956 (AGCA).

${ }^{21}$ Decree no 4198 of 13 July 1956 (AGCA).

${ }^{22}$ Decree $n^{\circ} 153$ of 17 April 1957 (AGCA).

${ }^{23}$ Decree n $^{\circ} 208$ of 12 June 1957 (AGCA).

24 “Inauguració d'un 'banc immobiliari i mercantil”", L'independant, 29 Aug. 1957, "En Andorra se abre un nuevo banco", Diario de Barcelona, 1 Sept. 1957, “Apertura bancaria en Andorra”, El Noticiero Universal, 3 Sept. 1957 (NAA press clipping). 
${ }^{25}$ Letter of the chief magistrates to the General Council on 2 September 1957 (AGCA).

${ }^{26}$ For more information on the peseta's rate of exchange in Tangier, see Pick (1957, p. 269). My thanks go to Dr. Jordi Catalan for generously alerting me to this source.

${ }^{27}$ The most common foreign currencies used when opening an account in the principality, according to information provided by professionals in the sector, were the US dollar, the British pound, the German mark, the Swiss franc and the Swedish krona. Sogues (1975, p. 322) estimates that the relative weight of foreign currency balances in Andorra in 1975 exceeded 65\%. Arasanz (1986, p. 95) notes that by 1982 foreign currency balances in the main Andorran banks were in the region of $80 \%$.

${ }^{28}$ Notice of 21 April 1959 establishing that: 1. Payment for goods not intended for import were forbidden; 2. Opening bank accounts for non-residents was forbidden; 3. Shareholders and shares in banks had to be submitted formally in writing, and 4. Inspectors were appointed by the General Council (Fiter 1973, p.442).

29 Julio Muñoz Ramonet (Barcelona, 1912 - St. Gallen, 1991) was a leading cotton businessman in the Spanish post-war period. Thanks to his contacts with the Franco regime, he was able to secure cotton import licenses that enabled him to amass a large fortune. In 1946 he married Carmen Villalonga, who was the daughter of Ignacio Villalonga, chairman of the Banco Central Español. He diversified his business holdings, becoming the owner of Barcelona's El Águila Mall, the city's Ritz Hotel, property development companies, the insurer La Compañía Internacional de Seguros and two Swiss banks: Banque Genevoise de Commerce et Crèdit and Schweizerische Spar- und Kreditbank - St. Gallen, both of which collapsed in 1965. The insurance company also collapsed, exposing a series of irregularities that forced Muñoz into exile in Switzerland in order to avoid being incarcerated in Spain (Cabana 1996, p.186-90).

${ }^{30}$ Letter of the chief magistrates to the General Council on 17 November 1970, record number 1256-se (AGCA).

${ }^{31}$ Siaguins dates back to an office set up by the Spanish central bank in the nineteen-forties in Rue des Siaghins in Tangier. The aim of the office was to intervene in the black market for pesetas. With the peseta's foreign convertibility in 1959 , the Sociedad Siaguins was created as a subsidiary of the Spanish central bank and the Tangier office moved to Zurich. The objectives of the subsidiary were to sell pesetas to anyone requesting them, thereby avoiding scarcity and pushing the exchange rate higher, and to buy any pesetas offered on the international market asking no questions about their place of origin, thereby 
ensuring that any excess of pesetas would not put downward pressure on the currency's exchange rate. In the early eighties, this mission devolved to the Banco Exterior de España in Switzerland (Martinez, J. A. "El Banco de España delega en el Banco Exterior en Suiza la compra-venta de pesetas en el mercado internacional" El Pais, 22 Aug. 1982).

${ }^{32}$ Reixach. J, “Andorra S.A.”, Diari de Barcelona, 26 Dec. 1987, cited by Lluelles (1991, p. 435).

${ }^{33}$ Directive 88/361/EEC of the European Economic Community.

${ }^{34}$ Council Directive 2003/48/EC. 


\section{Bibliographical references:}

ARASANZ, S. (1986). Descripció del sistema bancari andorrà. Undergraduate Thesis. Universitat de Barcelona. Facultat de Ciències Econòmiques i Empresarials.

ASSELAIN, J. C. (1984). Histoire économique de la France du XVIIIe siècle à nos jours. Éditions du Seuil. 2011 Edition.

ASSELAIN, J. C. (2002). "Le siècle des devaluations". Conference made in Le Ministère de 1'Economie et des Finances de France. 4 February 2002.

BECATTINI, G. (1987). Mercato e forze locali: il distretto industriale, Bologna, Il Mulino.

BERGMAN, E. M. (2006). The sustainability of clusters and regions at Austria's accession edge. In N. Bochniarz and G. B. Cohen (eds.), The Environment and Sustainable Development in The New Central Europe, New York: Berghahn.

BERGMAN, E. M. (2008). Cluster life-cycles: an emerging synthesis. In C. Karlsson (ed.), Handbook of Research in Cluster Theory. Edward Elgar Publishing. Cheltenham.

BRICALL, J. M (dir.) (1975). Estructura i perspectives de l'economia andorrana. Edicions 62. Barcelona. 
BRUSCO, S. (1982). The Emilian Model: Productive Descentralisation and Social Integration. Cambridge Journal of Economics, 6, pp. 167-184.

CABANA, F. (1996). La Burgesia catalana. Una aproximació històrica. Proa.

CABANA, F. (2005). 75 anys de banca i d'història andorrana. Andbanc. Andorra.

CARRERAS, A., TAFUNELl, X. (2004). Historia Económica de la España contemporánea (1789-2009). Crítica. Barcelona.

CASSANY, J. (1999). Memòries polítiques del senyor Josep Cassany i Grau (19301999). Pagès Editors. Lleida.

CATALAN, J. (1993). Economía e Industria: La ruptura de posguerra en perspectiva comparada. Revista de Historia Industrial, 4, pp. 111-42

CATALAN, J. (1995). Sector exterior y crecimiento industrial. España y Europa, 19391959. Revista de Historia Industrial, 8, pp. 99-145

CATALAN, J. (2003). La reconstrucción franquista y la experiencia europea occidental, 1934-1959. In C. Barciela (ed.), Autarquía y mercado negro. El fracaso económico del primer franquismo, 1939-1959, Crítica, Barcelona. 
CHANDLER. A. (1977). The visible hand. The Managerial Revolution in American Business, Cambridge, Mass., Harvard Belknap.

CHANG, H. -J. (2004). Retirar la escalera. La estrategia del desarrollo en perspectiva histórica. Catarata. Madrid.

CHANG, H. -J (2012). 23 cosas que no te cuentan sobre el capitalismo. Debate. Barcelona.

COMAS D’ARGEMIR, D. (2002). Andorra, una economia de frontera, Pagès Editors, Lleida.

EICHENGREEN, B. (1996). Globalizing Capital: A history of the international monetary system, Princeton University Press. 2000 Spanish Edition. Antoni Bosch, Editor.

EICHENGREEN, B. (2007). The European economy since 1945: Coordinated capitalism and beyond. Princeton University Press.

FITER, R. (1973). Legislació administrativa d'Andorra. Col·lecció Monumenta Andorra, vol V, Casal i Vall, Andorra.

GALABERT, M. (2012). Un cas d'èxit als Pirineus: El desenvolupament econòmic d'Andorra, 1866-2007. Recerques, 64, pp. 55-88 
GARCIA, G. (2001). El sistema financer. In J. M. Bricall (dir.), L'economia andorrana en el canvi de segle. Fundació Julià Reig. Andorra.

GIRAL, E. (1988). La Radiodifusión en Andorra: política, economía y espacio comunicacional en un país dependiente. Facultat de Ciències Econòmiques i Empresarials de la Universitat de Barcelona ( $\mathrm{PhD}$ Thesis).

GURDÓ, G. (2002). Banc Internacional-Banca Mora. Cinquantè aniversari, Andorra. BIBM.

GUYOMARCH, A. (1999). France. In M. S. Schulze (ed.), Western Europe: Economic and social change since 1945. Longman. London and New York.

International Monetary Fund (2007). Andorra: Assesment of Financial Sector Supervision and Regulation. IMF Country Report No. 07/69.

KLEPPER, S. (1997). Industry life cycle. Industrial and Corporate Change, 6, pp.145 11

LANDES, D. (1988). Piccolo e bello. Ma e bello davvero? In D. Landes (ed.) A che servono i padroni? Le alternative storiche dell'industrializzazione, Torino, Bollati Boringhieri. 
LLUELLES, M. J. (1991). La trasformació econòmica d'Andorra. Avenç. Barcelona.

LLUELlES M. J. (Coord.) (2004). El segle XX: La modernització d'Andorra, Pagès Editors. Lleida.

MAGGIONI, M. A. (2005). The rise and fall of industrial clusters: Tecnology and the life cycle of región. Institut d'Economia de Barcelona, Espai de Recerca en Economia, Facultat de Ciències Econòmiques i Empresarials, Universitat de Barcelona.

MARKUSEN, A. (1996). Stiky Places in Slippery Space: A Typology of Industrial Districts. Economic Geography, 72, pp. 293-313

MASKELL, P. i KEBIR, L. (2005). What Qualifies as a Cluster Theory. DRUID Working Paper No 0509, Department of Industrial Economics and Strategy, Copenhagen Business School.

MENZEL, M. P. i FORNAHL, D. (2007). Cluster life cycles: Dimensions and rationales of cluster development. Jena Economic Research Papers 2007-076, Friedrich-Schiller-University and Max Plank Institute, Jena.

NADAL, J. i SUDRIÀ, C. (1981). Història de la Caixa de Pensions. Edicions 62. Barcelona.

PICK, F. (various years). Pick's Currency Yearbook. Pick Publishing Corporation. New 
York.

ROJO, L. A. (1987). La crisis de la economía española, 1973-1984. In J. Nadal, A. Carreras and C. Sudrià. (comp.) La economía española en el siglo XX. Una perspectiva histórica, Ariel. Barcelona.

RUIZ, J. M (2007). La bancarización en Latinoamerica. Un desafío para los grupos bancarios españoles. Estabilidad Financiera, 13, pp. 125-137. Banco de España.

SÁEZ, X. (2004). La consolidació: de 1970 al segle XXI. In M. J. Lluelles (Coord). El segle XX: La modernització d'Andorra, Pagès Editors. Lleida.

SAINT-PAUL, G. (1993). Economic reconstruction in France: 1945-1958. In R. Dornbusch, R. Layard and W. Nölling (eds.) Post-War Reconstruction in Europe. MIT Press.

SANSA, J. (2001). Legislació del sistema financer del Principat d'Andorra. Fundació Julià Reig. Andorra.

SÉDILLOT, R. (1979). Histoire du Franc. Éditions Sirey.

SERRANO, C. (1998). Historia del Banco Popular Español (1926-1998) y de su filial regional el banco de Andalucía. Servicio de publicaciones e intercambio científico. Universidad de Málaga. 
SERRANO, J. M. and ASENSIO, M. J. (1997). El ingenierismo cambiario. La peseta en los años del cambio múltiple 1948-1959. Revista de Historia Económica, Año XV, 3, pp. $545-73$

SFORZI, F. (2009). The empirical evidence of industrial districts in Italy. In G. Becattini, M. Bellandi and L. De Propis (eds.) A Handbook of Industrial Districts, Edward Elgar.

SOGUES, J. (1975). La circulació financera. In J. M. Bricall (Dir.) Estructura $i$ perspectives de l'economia andorrana. Edicions 62. Barcelona.

SWANN, G. M. P. (2002). Towards a model of clustering in high-tecnology industries. In G. M. P. Swann, M. Prevezer and D. Stout (eds.) The Dynamics of Industrial Clustering, Oxford: Oxford University Press.

TICHY, G. (1998). Clusters: less dispensable and more risky than ever. In M. Steiner (ed.) Clusters and Regional Specialization: On geography, Technology and Networks, London: Pion.

TURRÓ, A. (2007). Les Emissions monetàries oficials de la Guerra Civil (1936-1939). Societat Catalana d'Estudis Numismàtics. Barcelona. 
VIÑAS, A. (et al) (1979). Política comercial exterior en España: 1931-1975. Banco Exterior de España. Servicio de Estudios Económicos, Madrid. 